\title{
Antimicrobial activity, toxicity and anti- inflammatory potential of methanolic extracts of four ethnomedicinal plant species from Punjab, Pakistan
}

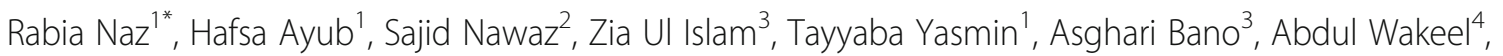
Saqib Zia ${ }^{4}$ and Thomas H. Roberts ${ }^{5}$

\begin{abstract}
Background: The plant species Aristolochia indica (AI), Melilotus indicus (MI), Tribulus terrestris (TT) and Cuscuta pedicellata (CP) are widely used in folk medicine in the villages around Chowk Azam, South Punjab, Pakistan. The aim of this study was to evaluate the antioxidant activity, phytochemical composition, and the antibacterial, antifungal, cytotoxic and anti-inflammatory potential of the four medicinal plants listed above.

For CP stem, this study represents (to the best of our knowledge) the first time phytochemicals have been identified and the antioxidant and anti-inflammatory potential determined.

Methods: Phytochemicals were analyzed through chemical tests, thin layer chromatography (TLC) and spectrophotometric methods. Antioxidant activities (DPPH and $\mathrm{H}_{2} \mathrm{O}_{2}$ ) were also determined through spectrophotometric methods. Extracts were evaluated for antibacterial potential via the agar well diffusion method against Staphylococcus aureus, Pseudomonas aeruginosa, Klebsiella pneumonia and Acinetobacter baumannii. The minimal inhibitory concentration (MIC) and minimal bactericidal concentration (MBC) were determined by the microdilution method. Antifungal activities were tested using the agar tube dilution method against three species: Aspergillus fumigatus, Aspergillus flavus and Rhizopus oryzae. The cytotoxic potential of the plant extracts was checked using the brine shrimp assay. In vitro anti-inflammatory activity of the selected plant extracts was evaluated using albumin denaturation, membrane stabilization and proteinase inhibitory assays.

Results: Of all the methanolic extracts tested, those from CP (stem) and TTF (T. terrestris fruit) had the highest phenolic,

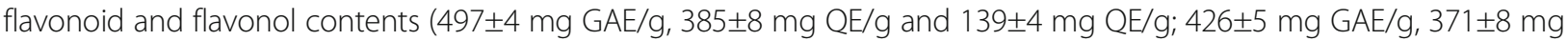
$\mathrm{QE} / \mathrm{g}$ and $138 \pm 6 \mathrm{mg} \mathrm{QE} / \mathrm{g}$, respectively) and also exhibited strong antioxidant potential in scavenging DPPH and hydrogen peroxide ( $\mathrm{I}_{50}$ values; $20 \pm 1$ and $18 \pm 0.7 \mu \mathrm{g} / \mathrm{mL} ; 92 \pm 2$ and $26 \pm 2 \mu \mathrm{g} / \mathrm{mL}$, respectively). CP, TTF and TTL (T. terrestris leaf) extracts substantially inhibited the growth of the bacteria A. baumannii, S. aureus, and K. pneumonia and also exhibited the highest antifungal potential. The ranking of the plant extracts for cytotoxicity was $T \mathrm{TF}>T \mathrm{~L}>\mathrm{Al}>\mathrm{CP}>\mathrm{Ml}$, while the ranking for in vitro anti-inflammatory potential at a concentration of $200 \mu \mathrm{g} / \mathrm{mL}$ of the selected plant extracts was $\mathrm{CP}>\mathrm{TL}$, TTF $>\mathrm{Al}>\mathrm{MI}$. The lowest IC $\mathrm{C}_{50}$ (28 $\mu \mathrm{g} / \mathrm{mL}$ ) observed in the albumin denaturation assay was for CP. Positive correlations were observed between total phenolics, antioxidants, antibacterial, antifungal and anti-inflammatory potential of the selected plant extracts, indicating a significant contribution of phenolic compounds in the plant extracts to these activities. (Continued on next page)
\end{abstract}

\footnotetext{
* Correspondence: rabia.naz@comsats.edu.pk

'Department of Biosciences, COMSATS Institute of Information Technology,

Islamabad, Pakistan

Full list of author information is available at the end of the article
} 
(Continued from previous page)

Conclusions: This study revealed the strong antimicrobial, antioxidant, cytotoxic and anti-inflammatory potential of the plant species CP and $\Pi$ used in folk medicine.

Keywords: Plant extracts, Phytochemicals, TLC, Antimicrobials, Antioxidants, Cytotoxicity, Anti-inflammatory, Anti-proteinase, Chowk Azam

\section{Background}

Tissues of many plants species contain secondary metabolites with the potential to combat disease-causing micro-organisms. These compounds include glycosides, saponins, flavonoids, steroids, tannins, alkaloids and terpenes [1]. Extracts of different plant organs, including roots, leaves, bark, flowers, fruits and seeds, may contain distinct phytochemicals with activity against bacterial or fungal pathogens [2]. In folk medicine, a single plant species is often used to treat more than one type of disease or infection [3]. Extracts of plants with a history of traditional use should be tested using modern methods for activities against human pathogens, with the aim of discovering potential new drugs.

Inflammatory diseases comprising various kinds of rheumatism are common all over the world [4]. Although rheumatism is the oldest known human disease, limited progress has been made for its permanent treatment. Non-steroidal anti-inflammatory drugs (NSAIDs) are being used to cure and control inflammation, fever and pain. However, their use has not been therapeutically efficacious in all types of inflammations. Furthermore, the use of NSAIDs can cause adverse side-effects leading to hemorrhage and ulcers [5].

Pakistan has a rich diversity of medicinal and aromatic plants due to its unique phytogeography with diverse climatic conditions. The Chowk Azam town to the east of district Layyah lies in the sub-tropical continental plain of Pakistan, which features sandy soil. The climate is extremely hot in summer, while in winter temperatures can drop to $0{ }^{\circ} \mathrm{C}$. People living in the villages around Chowk Azam rely mainly on medicinal plants to treat their minor diseases, and in some cases major diseases like cancer and hepatitis [6].

Four medicinal plants were studied here: Aristolochia indica (Aristolochiaceae), a creeper plant, perennial herb or shrub [7]; Cuscuta pedicellata (Convolvulaceae), a holoparasitic annual that is usually observed as dense tangles of fine, yellow-orange, heavily-branched stems in the foliage of host plants [8]; Melilotus indicus (Fabaceae), an annual noxious weed of crop fields, gardens, orchards and canal banks [9] and Tribulus terrestris (Zygophyllaceae), which features a stem that remains close to the ground, covered with lint [10]. These plants are used by the local community in the villages of Chowk Azam in the district Layyah, Pakistan, for the treatment of various skin infections/irritations, poisonous bites, inflammation and some other infectious diseases (Table 1).

Key techniques employed in this study include the brine shrimp lethality and cytotoxicity assays, which are known to detect a wide range of bioactivities in plant crude extracts. The lethality potential of plant extracts to brine shrimp is an effective method of prescreening prior to conducting more elaborate antitumor and cytotoxicity assays. Numerous studies have reported the use of the brine shrimp assay to screen plant extracts for activities against fungi, arthropod pests (including insect larvae) and molluscs, as well as their anticancer and cytotoxic potential. The cytotoxicity brine shrimp assay has also been used successfully as a step in the identification of antineoplastic, cytotoxic, antimalarial, antifeedant and insecticidal compounds from many plants [11].

The aim of this study was to determine whether the selected plant extracts can control the growth of pathogenic microorganisms. We focused on the phytochemical, antioxidant, antimicrobial, cytotoxicity and antiinflammatory properties of the four medicinal plant species.

\section{Methods}

\section{Chemicals and collection of plant materials}

Methanol, Folin-Ciocalteu reagent, 2,2-diphenyl-1picrylhydrazyl (DPPH), quercetin, rutin, gallic acid, aluminum chloride, potassium acetate, sodium acetate, ascorbic acid, hydrogen peroxide, phosphate buffer, nutrient broth, dimethyl sulfoxide (DMSO), potato dextrose agar, terbinafine, streptomycin, bovine serum albumin (BSA), casein, perchloric acid, aspirin, Tris- $\mathrm{HCl}$, and trypsin were purchased from Sigma-Aldrich. All reagents and chemicals were of analytical grade.

Samples of the plant species Aristolochia indica (AI), Cuscuta pedicellata (CP) (stems), Melilotus indicus (MI) and Tribulus terresteris fruit (TTF) and leaf extracts (TTL) were collected from Chowk Azam, Layyah District, Punjab, Pakistan. The plants were identified by Prof. Dr. Mir Ajab Khan, Department of Botany, Quaid-iAzam University. The plant species were selected on the basis of reports obtained from traditional herbalists and local people that extracts are used mainly to treat various infectious diseases. The scientific, English and local names, the parts of the plants extracted traditionally, their 
Table 1 Profile of ethnomedicinal use of selected medicinal plants, botanical/English/local name used, route of administration and plant extract yield obtained in the present study

\begin{tabular}{|c|c|c|c|c|c|c|}
\hline Sample no. & Botanical name, family & English name/Local name & Parts used & Ethnomedicinal use & $\begin{array}{l}\text { Route of } \\
\text { administration }\end{array}$ & Yield (\%) \\
\hline 1 & $\begin{array}{l}\text { Aristolochia indica L., } \\
\text { Aristolochiaceae }\end{array}$ & Birthwort,wort killer/ Hukka-bel & Leaves & $\begin{array}{l}\text { To cure poisonous bite, inflammations, } \\
\text { reduce itching, leprocy, gastric } \\
\text { stimulant, diarrhoea, intermittent fever, } \\
\text { cough }\end{array}$ & Topical, Oral & 31 \\
\hline 2 & $\begin{array}{l}\text { Cuscuta pedicellata Ledeb, } \\
\text { Convolvulaceae }\end{array}$ & $\begin{array}{l}\text { Clover dodder/ Loot booti (Saraiki) } \\
\text { Akash-bail/Amar-bail (Urdu) }\end{array}$ & Stem & $\begin{array}{l}\text { stomachache, to cure wounds, cuts, } \\
\text { used as purgative, anti-inflammatory } \\
\text { and to treat high blood pressure }\end{array}$ & Oral, Topical & 17 \\
\hline 3 & $\begin{array}{l}\text { Melilotus indicus L., } \\
\text { Fabaceae }\end{array}$ & $\begin{array}{l}\text { Yellow melilot (English) Sweet } \\
\text { clover/ Sinjee }\end{array}$ & Leaves & $\begin{array}{l}\text { To cure inflammations and skin } \\
\text { irritation, astringent, anticoagulant, } \\
\text { laxative }\end{array}$ & Oral, Topical & 29 \\
\hline 4 & $\begin{array}{l}\text { Tribulus terresteris L., } \\
\text { Zygophyllaceae }\end{array}$ & Puncture clover/ Bhakra, Gokhru & Leaves & $\begin{array}{l}\text { anti-inflammatory, lithotriptic, diuretic, } \\
\text { general tonic }\end{array}$ & & 37 \\
\hline 5 & Tribulus terresteris & & Fruit & $\begin{array}{l}\text { anti-inflammatory, effective in most of } \\
\text { Gynecological and genitourinary } \\
\text { disorders, Gonorrhoea and to treat } \\
\text { abdominal distension }\end{array}$ & Topical, Oral & 33 \\
\hline
\end{tabular}

ethnomedicinal uses, route of administration and extract yields for the four plant species are described in Table 1.

\section{Preparation of plant extracts}

Plant leaves, stems and fruits of the selected plant species were washed thoroughly with distilled water and shade-dried for $3 \mathrm{~d}$ at room temperature. The dried leaves, stems and fruits were uniformly ground using an electric grinder. The powdered plant material (250 g) was extracted for $4 \mathrm{~d}$ in $1 \mathrm{~L} 100 \%$ methanol [12]. The separated extracts were then filtered through Whatman No. 1 filter paper and the methanol filtrate evaporated to dryness using a rotary evaporator at room temperature $\left(30{ }^{\circ} \mathrm{C}\right)$. The thick extracted mass was then dried at room temperature, and the dried extract stored in an air-tight container at $4{ }^{\circ} \mathrm{C}$ until further use.

\section{Determination of plant extract yield (\%)}

Yield percentage $(w / w)$ from the dried extracts was calculated as:

$$
\text { Yield }(\%)=(\mathrm{W} 1 * 100) / \mathrm{W} 2
$$

where W1 is the dry weight of extract after evaporating the solvent and W2 is the weight of the soaked plant powder.

\section{Preliminary phytochemical screening}

Phytochemical screening of the selected plant extracts was performed to detect the presence of phytochemical constituents, including saponins, terpenoids [12], anthraquinones, phlobatannins [13], flavonoids and phenolic compounds [14].

\section{Thin layer chromatography}

The methanolic plant extracts $(10 \mu \mathrm{L})$ were applied on pre-coated TLC plates using capillary tubes and air dried. The TLC plates were developed in a chamber using chloroform: methanol (5:1) as the mobile phase and observed under UV light (254 nm). Caffeic acid, quercetin, rutin, trans-cinnamic acid and salicylic acid were used as standards.

The mobility of the samples was expressed as retention factor $(\mathrm{R} f)$ as calculated using the following formula:

$$
\mathrm{R} f=\frac{\text { Distance travelled by the solute }(\mathrm{cm})}{\text { Distance travelled by the solvent }(\mathrm{cm})}
$$

\section{Quantitative analysis of phytochemicals Total phenolic content}

Total phenolic content was analyzed using the FolinCiocalteu colorimetric method [15] with some modifications. An aliquot of $0.3 \mathrm{~mL}$ of the plant extract was mixed with Folin-Ciocalteu phenol reagent $(2.25 \mathrm{~mL})$. After $5 \mathrm{~min}, 6 \%$ sodium carbonate $(2.25 \mathrm{~mL})$ was added and the mixture was allowed to stand at room temperature for $90 \mathrm{~min}$. The absorbance of the mixture was measured at $725 \mathrm{~nm}$ in a spectrophotometer (HITACHI Model: U-1100 $573 \times 415$ ). A calibration curve for gallic acid in the range $20-80 \mu \mathrm{g} / \mathrm{mL}$ was prepared in the same manner. Results were expressed as mg gallic acid equivalent (GAE) per gram extract.

\section{Total flavonoid content}

Total flavonoid content was determined using the aluminum chloride colorimetric method [16, 17] with some modifications. A calibration curve for quercetin in 
the range $20-80 \mu \mathrm{g} / \mathrm{mL}$ was prepared. Plant extract $(0.5 \mathrm{~mL})$ and standard $(0.5 \mathrm{~mL})$ were placed in separate test tubes and $10 \%$ aluminum chloride $(0.1 \mathrm{~mL}), 1 \mathrm{M}$ potassium acetate $(0.1 \mathrm{~mL}), 80 \%$ methanol $(1.5 \mathrm{~mL})$ and distilled water $(2.8 \mathrm{~mL})$ added and mixed. A blank was prepared in the same manner but $0.5 \mathrm{~mL}$ of distilled water was used instead of the sample or standard. All tubes were incubated at room temperature for $30 \mathrm{~min}$ and the absorbance was read at $415 \mathrm{~nm}$. The concentration of flavonoid was expressed as mg quercetin equivalent (QE) per gram extract. Each plant extract was made in triplicate.

\section{Total flavonol content}

Total flavonol content was determined following the aluminum chloride colorimetric method $[18,19]$ with some modifications. A calibration curve for quercetin in the range $20-80 \mu \mathrm{g} / \mathrm{mL}$ was prepared., Extract $(1 \mathrm{~mL})$ and standard $(1 \mathrm{~mL})$ were placed in separate test tubes and $2 \%$ aluminum chloride $(1 \mathrm{~mL}), 5 \%$ sodium acetate $(3 \mathrm{~mL})$ added and mixed. The mixture was then centrifuged at $3000 \mathrm{rpm}$ for $20 \mathrm{~min}$ to obtain a clear solution. The absorbance was read at $440 \mathrm{~nm}$ and the results expressed as mg quercetin equivalent (QE) per gram of extract. Each plant extract was prepared in triplicate.

\section{DPPH radical scavenging activity}

The free radical scavenging activity of the selected plant extracts was measured in vitro via the 2, 2' - diphenyl-1picrylhydrazyl $(\mathrm{DPPH})$ assay $[20,21]$. The reaction mixture $(3 \mathrm{~mL})$ consisted of $1 \mathrm{~mL}$ DPPH $(0.3 \mathrm{mM})$ in methanol, $1 \mathrm{~mL}$ extract and $1 \mathrm{~mL}$ methanol. The radical scavenging activity of the samples at various concentrations $(25-200 \mu \mathrm{g} / \mathrm{mL})$ was measured. The reaction mixture was shaken well and incubated in the dark for $10 \mathrm{~min}$ at room temperature. Absorbance was read at $517 \mathrm{~nm}$. The control was prepared as above but without any plant sample. Ascorbic acid [22] and rutin [23] were used as positive controls.

Scavenging activity was estimated based on the percentage of DPPH radical scavenged according to the following equation:

$$
\begin{aligned}
& \text { Scavenging effect } \% \\
& =[(\text { control absorbance-sample absorbance }) \\
& \quad /(\text { control absorbance })] \times 100
\end{aligned}
$$

\section{Hydrogen peroxide radical $\left(\mathrm{H}_{2} \mathrm{O}_{2}\right)$ scavenging assay}

The ability of plant extracts to scavenge hydrogen peroxide was determined according to the method of Ruch et al. (1989) [24]. A solution of hydrogen peroxide (2 $\mathrm{mM}$ ) was prepared in phosphate buffer $(50 \mathrm{mM}$, $\mathrm{pH}$ 7.4). Plant extracts $(25-200 \mu \mathrm{g}$ powder/mL) were prepared in distilled water, and aliqots $(0.1 \mathrm{~mL})$ transferred into vials and their volumes made up to $0.4 \mathrm{~mL}$ with $50 \mathrm{mM}$ phosphate buffer ( $\mathrm{pH}$ 7.4). After addition of $0.6 \mathrm{~mL}$ hydrogen peroxide solution, tubes were vortexed and the absorbance was determined at $230 \mathrm{~nm}$ after 10 min against a blank solution containing phosphate buffer without hydrogen peroxide. Ascorbic acid [25] and rutin were used as positive controls.

The ability of the extract to scavenge hydrogen peroxide was calculated using the following equation:

$$
\text { \%Scavenged }\left[\mathrm{H}_{2} \mathrm{O}_{2}\right]=\left[\left(\mathrm{A}_{\mathrm{C}}-\mathrm{A}_{\mathrm{S}}\right) / \mathrm{A}_{\mathrm{C}}\right] \times 100
$$

where $A_{C}$ and $A_{S}$ are the absorbance of the control and sample, respectively.

\section{Pathogenic bacterial and fungal strains used Bacteria}

The bacterial pathogens used were Acinetobacter baumannii (ATCC 17978), Staphylococcus aureus (ATCC 6538), Pseudomonas aeruginosa (ATCC 7221) and Klebsiella pneumoneae (ATCC 6059), which were obtained from the Department of Microbiology, Quaid-i-Azam University, Islamabad, Pakistan.

\section{Fungi}

The fungal pathogens Aspergillus flavus (FCBP-PTF1265) and Aspergillus fumigatus (FCBP-MF-923) were obtained from the First Fungal Culture Bank of Pakistan (FCBP), University of the Punjab, Pakistan. Rhizopus oryzeae (ATCC 11886 (AY 803930)) was obtained from the Department of Microbiology, Quaid-i-Azam University, Islamabad.

The bacterial isolates were first sub-cultured in a nutrient broth (Sigma) and incubated at $37{ }^{\circ} \mathrm{C}$ for $18 \mathrm{~h}$. The fungal isolates were sub-cultured on potato dextrose agar (PDA) (Merck) for $7 \mathrm{~d}$ at $25^{\circ} \mathrm{C}$.

\section{Positive and negative controls}

Streptomycin $(30 \mu \mathrm{g} / \mathrm{mL})$ and terbinafine $(1 \mathrm{mg} / \mathrm{mL})$ were used as positive controls for the antibacterial and antifungal tests, respectively. DMSO was used as negative control for the antibacterial and antifungal analyses.

\section{Assay for antibacterial activity}

Antibacterial activity of the methanol extracts of the selected plant species was determined using the agar well diffusion method [26]. Petri plates were prepared by pouring $75 \mathrm{~mL}$ of seeded $\mathrm{MH}$ agar and allowing the agar to solidify. Freshly prepared bacterial inoculum was evenly spread using a sterile cotton swab on the entire agar surface. A hole was then punched with a sterile cork borer $(6 \mathrm{~mm})$ and $100 \mu \mathrm{L}$ of each crude extract was poured into the well. Petri plates were then allowed to 
stand at room temperature for $1 \mathrm{~h}$ and incubated at $37{ }^{\circ} \mathrm{C}$ overnight. Controls were run in parallel whereby solvent was used to fill the well. The plates were observed for zones of inhibition after $24 \mathrm{~h}$ and the results compared with those of the positive control, streptomycin $(30 \mu \mathrm{g} / \mathrm{mL})$.

\section{Determination of minimum inhibitory concentration (MIC) and minimum bactericidal concentration (MBC)}

The determination of MIC of the methanolic extracts of the selected plant species was carried out by the microdilution method [27] using nutrient broth. Plant extracts were dissolved in $10 \%$ DMSO and two-fold dilutions were prepared with culture broth. Each test sample and growth control (containing broth and DMSO, without plant extract/antimicrobial substance) was inoculated with $10 \mu \mathrm{L}$ of bacterial suspension containing $5 \times 10^{6} \mathrm{CFU} / \mathrm{mL}$. A $10-\mu \mathrm{L}$ solution of resazurin $(270 \mathrm{mg}$ resazurin tablet dissolved in $40 \mathrm{~mL}$ of sterile water) was also added to each sample and incubated for $24 \mathrm{~h}$ at $37{ }^{\circ} \mathrm{C}$. Bacterial growth was detected by reading absorbance at $500 \mathrm{~nm}$. Bacterial growth was indicated by a color change from purple to pink or colorless (assessed visually). MIC was defined as the lowest plant extract concentration at which the color changed, or the highest dilution that completely inhibited bacterial growth. The test dilutions were further sub-cultured on fresh solid media and incubated for $18 \mathrm{~h}$ to determine the $\mathrm{MBC}$ values. The lowest plant extract concentration (highest dilution) that killed all the bacteria was defined as MBC. Experiments were carried out in triplicate to test each dilution for each bacterial strain to determine MIC and $\mathrm{MBC}$ values.

\section{Assay for antifungal activity}

The agar tube dilution method was used for the determination of antifungal activity of the methanol extracts of the selected plant species [28]. Samples were prepared by dissolving crude plant extract in DMSO. Culture media was prepared by dissolving $6.5 \mathrm{~g}$ of potato dextrose agar per $100 \mathrm{~mL}$ distilled water $(\mathrm{pH}$ 5.6). Potato dextrose agar $(10 \mathrm{~mL})$ was dispensed in screw-capped tubes or cotton-plugged test tubes and autoclaved at $121{ }^{\circ} \mathrm{C}$ for $21 \mathrm{~min}$. Tubes were allowed to cool at $50{ }^{\circ} \mathrm{C}$ and the potato dextrose agar was loaded with $67 \mu \mathrm{L}$ of extract pipetted from the stock solutions. The tubes containing the media were then allowed to solidify in slanting position at room temperature. The tubes containing solidified media and plant extract were inoculated with a 4-mm-diameter piece of inoculum taken from a $7 \mathrm{~d}$-old culture of fungus. Controls were run in parallel whereby the respective solvent was used instead of plant extract. The test tubes were incubated at $28{ }^{\circ} \mathrm{C}$ for $7 \mathrm{~d}$. Cultures were examined twice weekly during the incubation. Readings were taken by measuring the linear length $(\mathrm{mm})$ of fungus in the slant, and growth inhibition was calculated with reference to negative control. The experiments were performed in triplicate.

Percentage inhibition of fungal growth for each concentration of compound was determined as:

$$
\begin{aligned}
& \text { Percentage inhibition of fungal growth } \\
& \quad=100-\frac{\text { Linear growth in test }(\mathrm{mm})}{\text { Linear growth in control }(\mathrm{mm})} \times 100
\end{aligned}
$$

\section{Cytotoxic brine shrimp assay}

Cytotoxic activity of the methanolic plant extracts was tested against brine shrimps hatched in saline solution (known as nauplii) [29]. Methanol extracts of the selected plant species were prepared to make final concentrations of 10, 100 and $1000 \mathrm{mg} / \mathrm{mL}$. An aliquot $(2 \mathrm{~mL})$ of each concentration was transferred to a graduated vial, kept for $48 \mathrm{~h}$ for solvent evaporation and then dissolved in DMSO before adding the nauplii. Brine shrimp eggs were hatched in a plastic rectangular container that was one-quarter filled with saline solution with general aeration. A plastic separator (with holes) for unequal compartmentation was placed in the container. Eggs were spread into the larger and darker compartment. After $48 \mathrm{~h}$, mature nauplii were collected from the smaller and illuminated side. Ten shrimps were transferred to each vial and saline solution was added to make the final volume $2 \mathrm{~mL}$. Vials were incubated at $25{ }^{\circ} \mathrm{C}$ for $24 \mathrm{~h}$, after which the survivors were counted with the aid of a $3 \times$ magnifying glass. DMSO and saline solution were used as negative controls and potassium dichromate as the reference standard.

Lethal dose was calculated by linear regression analysis [30].

Abbot's formula was used to calculate the percentage mortality:

$$
\% \text { Mortality }=(\text { Sample }- \text { control } / \text { control }) \times 100
$$

\section{Anti-inflammatory activity Inhibition of protein denaturation method}

Inhibition of protein denaturation was determined according to the method of Mizushima et al. [31] with some modifications. The reaction mixture contained the test extract at different concentrations and $1 \%$ BSA (aqueous solution). $1 \mathrm{~N} \mathrm{HCl}$ was used to adjust the $\mathrm{pH}$ of the reaction mixture. The samples were heated at $37{ }^{\circ} \mathrm{C}$ for $20 \mathrm{~min}$ and then $57{ }^{\circ} \mathrm{C}$ for $20 \mathrm{~min}$, and allowed to cool. The turbidity of the samples was measured at $660 \mathrm{~nm}$. The experiment 
was performed in triplicate. Percent inhibition of protein denaturation was calculated as follows:

Percentage inhibition $=\left(\mathrm{A}_{\mathrm{C}}\right.$ of control $-\mathrm{A}_{\mathrm{C}}$ of test sample $)$

$$
\left.\times 100 / A_{C}\right)
$$

where $A_{C}$ and $A_{S}$ are the absorbance (at $600 \mathrm{~nm}$ ) of the control and sample, respectively.

\section{Human red blood cell (HRBC) membrane stabilization test}

Fresh human blood $(10 \mathrm{ml})$ was collected in heparinized centrifuge tubes and centrifuged at $3000 \mathrm{rpm}$ for $10 \mathrm{~min}$ and washed $3 \times$ with an equal volume of normal saline solution. The volume of the blood was measured and reconstituted as a $10 \% \mathrm{v} / \mathrm{v}$ suspension with normal saline [32]. The reaction mixture $(2 \mathrm{ml})$ consisted of $1 \mathrm{ml}$ methanolic plant extract and $1 \mathrm{ml}$ of $10 \%$ red blood cell suspension. For the control, saline was added instead of plant extract. Aspirin was used as a standard drug (positive control). The samples were incubated at $56{ }^{\circ} \mathrm{C}$ for $30 \mathrm{~min}$, centrifuged at $2500 \mathrm{rpm}$ for $5 \mathrm{~min}$ and the absorbance of the supernatant measured at $560 \mathrm{~nm}$. The experiment was performed in triplicate. Percent membrane stabilization activity was calculated by the formula given in Inhibition of protein denaturation method section [33], while the percentage of protection was calculated using the following formula:

$$
\text { Percent of protection }=100-\mathrm{A}_{\mathrm{S}} / \mathrm{A}_{\mathrm{C}} \times 100
$$

where $A_{C}$ and $A_{S}$ are the absorbance (at $560 \mathrm{~nm}$ ) of the control and sample, respectively.

\section{Proteinase inhibitory assay}

The proteinase inhibitory assay was performed following the method modified by Oyedepo and Femurewa [34]. The reaction mixture $(2 \mathrm{ml})$ contained $0.06 \mathrm{mg}$ trypsin, $1 \mathrm{ml}$ Tris- $\mathrm{HCl}$ buffer $(20 \mathrm{mM}, \mathrm{pH} 7.4)$ and $1 \mathrm{ml}$ test plant extract sample at different concentrations. The reaction mixture was incubated at $37{ }^{\circ} \mathrm{C}$ for $5 \mathrm{~min}$ and then $1 \mathrm{ml}$ of $0.8 \%(w / v)$ casein was added. The mixture was incubated for an additional $20 \mathrm{~min}$. Perchloric acid ( $2 \mathrm{ml}$ of $70 \%$ ) was added to stop the reaction. The cloudy suspension was centrifuged and the absorbance of the supernatant was measured at $210 \mathrm{~nm}$ against Tris- $\mathrm{HCl}$ buffer as blank. The experiment was performed in triplicate.

\section{Statistical analysis}

Results were expressed as the mean \pm standard error of mean (SEM). The data generated from quantitative assays for phytochemicals and antifungal activity were subjected to ANOVA using Statistix version 8.1. Comparison among mean values was made by Least Significant Difference (LSD) to test significant differences at $P<0.05$ [35]. Linear regression analysis was used to calculate $\mathrm{IC}_{50}$ values. Linear correlations were analyzed by using regression in $\mathrm{R}$ software (3.2.2.).

\section{Results \\ Qualitative analysis of phytochemicals, TLC and determination of total phenolic, flavonoid and flavonol contents}

The qualitative analysis of phytochemicals revealed the presence of phenolics, flavonoids and terpenoids in all the selected plant extracts. Tannins were observed only in MI, AI and CP, whereas phlobatannins (tannins that with hot dilute acids yield a phlobaphene) were found only in CP and TTF. Anthraquinnone was present in significantly higher amounts in TTL followed by AI (Table 2).

Results obtained from thin layer chromatography confirmed the presence of different bioactive compounds in the various plant extracts (Table 3 ). In the leaf extracts of AI, a total of six spots appeared, among which none coincided with the mobility of the standard compounds used. TLC of stem extracts of CP gave a total of nine spots, among which one coincided with salicylic acid, one with trans-cinnamic acid and one with caffeic acid. TLC of leaf extracts of MI gave six spots, one of which had a mobility equal to that of quercitin. TLC of TTL gave six spots, among which one coincided with transcinnamic acid, while TTF gave nine spots, one of which conincided with trans-cinnamic acid and one with caffeic acid.

The quantitative analysis revealed that CP exhibited the maximum phenolic, flavonoid and flavonol contents (497, 385 and $139 \mathrm{mg} / \mathrm{g}$, respectively), followed by TTF (426, 371 and $138 \mathrm{mg} / \mathrm{g}$ ). The minimum phenolic and flavonoid contents were observed in the MI and AI, respectively (Table 4).

\section{Antioxidant activities}

The DPPH assay is commonly used to determine the antioxidant potential of plant extracts/compounds by

Table 2 Qualitative analyses of phytochemicals of selected plants

\begin{tabular}{llllll}
\hline Phytochemicals & $\begin{array}{l}\text { M. indicus } \\
\text { (leaf) }\end{array}$ & $\begin{array}{l}\text { A. indica } \\
\text { (leaf) }\end{array}$ & $\begin{array}{l}\text { C. pedicellata } \\
\text { (stem) }\end{array}$ & $\begin{array}{l}\text { T. terresteris } \\
\text { (fruit) }\end{array}$ & $\begin{array}{l}\text { T. terresteris } \\
\text { (leaf) }\end{array}$ \\
\hline Tannins & + & + & + & - & - \\
Flavonoids & +++ & +++ & +++ & ++ & + \\
Terpenoids & + & + & + & + & + \\
Phlobatannins & - & - & + & + & - \\
Anthraquinone & + & ++ & + & + & +++ \\
Phenolics & ++ & + & +++ & + & + \\
\hline
\end{tabular}

+++ Strongly positive

++ Moderately positive

+ Weakly positive

- Negative 
Table 3 Thin layer chromatography (TLC) of different parts of methanolic extracts of selected plants

\begin{tabular}{ll}
\hline Standards & Rf value \\
Caffeic acid & 0.85 \\
Quercitin & 0.38 \\
Rutin & 0.97 \\
trans-cinnamic acid & 0.74 \\
Salicylic acid & 0.6 \\
Plant extracts & Rf value \\
Aristolochia indica & $0.23,0.26,0.31,0.45,0.56,0.83$ \\
Cuscuta pedicellata & $0.16,0.2,0.25,0.35,0.45,0.61$, \\
& $0.75,0.83,0.85$ \\
Melilotus indicus & $0.20,0.25,0.34,0.37,0.56,0.83$ \\
Tribulus terresteris (leaf) & $0.16,0.25,0.30,0.45,0.75,0.83$ \\
Tribulus terresteris (fruit) & $0.16,0.20,0.27,0.35,0.48,0.56$, \\
& $0.75,0.83,0.85$ \\
\hline
\end{tabular}

measuring their ability to act as free radical scavengers. $\mathrm{IC}_{50}$ (the substrate concentration that causes $50 \%$ loss of $\mathrm{DPPH}$ ) is used to interpret the assay results. $\mathrm{IC}_{50}$ values of scavenging $\mathrm{DPPH}$ radicals for $\mathrm{CP}$ and TTF extracts were $20 \pm 1$ and $92 \pm 2 \mu \mathrm{g} / \mathrm{mL}$, respectively; their scavenging ability was found to be lower than that of ascorbic acid and rutin (5 \pm 0.4 , $18 \pm 0.5 \mu \mathrm{g} / \mathrm{mL}$ ) (Fig. 1). The DPPH scavenging activity was in the order of $\mathrm{CP}>\mathrm{TTF}>\mathrm{TTL}>\mathrm{AI}>\mathrm{MI}$ $\left(\mathrm{IC}_{50} 20 \pm 1,92 \pm 2,125 \pm 3,179 \pm 3,223 \pm 3 \mu \mathrm{g} / \mathrm{mL}\right.$, respectively).

The $\mathrm{IC}_{50}$ values of the selected plant extracts for $\mathrm{H}_{2} \mathrm{O}_{2}$ scavenging activity are presented in Fig. 1. CP and TTF extracts showed strong hydrogen peroxide radical scavenging activity $\left(\mathrm{IC}_{50} 18 \pm 0.7,26 \pm 2 \mu \mathrm{g} / \mathrm{mL}\right.$, respectively) whereas the standards ascorbic acid and rutin gave $\mathrm{IC}_{50}$ values of $4.5 \pm 0.4$ and $17 \pm 0.6 \mu \mathrm{g} / \mathrm{mL}$, respectively. The scavenging activity for hydrogen peroxide of selected plant extracts was in the order $\mathrm{CP}>$ TTF $>$ TTL $>$ AI $>$ MI.

Table 4 Total phenolics, flavonoid and flavonol content in the dried plant extracts

\begin{tabular}{llll}
\hline Plant material & $\begin{array}{l}\text { Total phenolic } \\
\text { content } \\
\text { (mg GAE/g) }\end{array}$ & $\begin{array}{l}\text { Total flavonoid } \\
\text { content } \\
\text { (mg QE/g) }\end{array}$ & $\begin{array}{l}\text { Total flavonol } \\
\text { content } \\
\text { (mg QE/g) }\end{array}$ \\
\hline A. indica & $335^{\mathrm{d}} \pm 5$ & $80^{\mathrm{d}} \pm 2$ & $72^{\mathrm{c}} \pm 3$ \\
C. pedicellata (stem) & $497^{\mathrm{a}} \pm 4$ & $385^{\mathrm{a}} \pm 8$ & $139^{\mathrm{a}} \pm 4$ \\
M. indicus & $224^{\mathrm{e}} \pm 4$ & $116^{\mathrm{c}} \pm 5$ & $109^{\mathrm{b}} \pm 4$ \\
T. terrestris (leaf) & $389^{\mathrm{c}} \pm 4$ & $370^{\mathrm{b}} \pm 6$ & $55^{\mathrm{d}} \pm 5$ \\
T. terrestris (fruit) & $426^{\mathrm{b}} \pm 5$ & $371^{\mathrm{b}} \pm 8$ & $138^{\mathrm{a}} \pm 6$ \\
\hline
\end{tabular}

Values are means $\pm \mathrm{SD}(n=3)$. Values in the same column followed by a different letter $(\mathrm{a}-\mathrm{d})$ are significantly different $(P<0.05)$

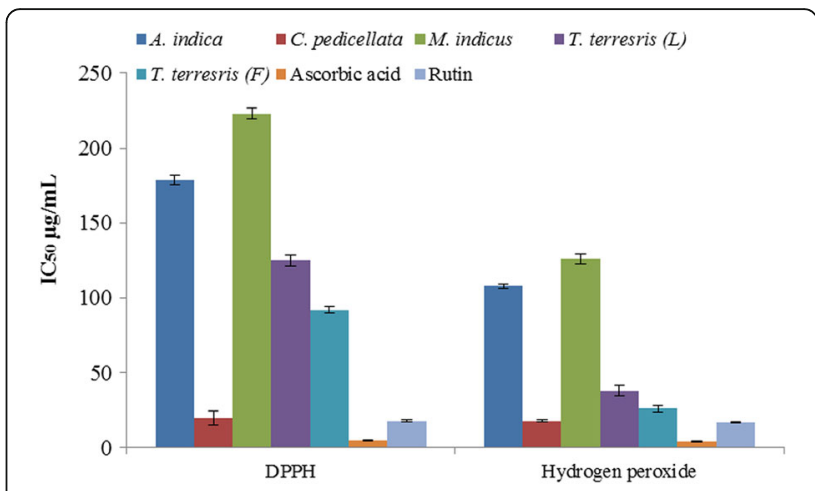

Fig. $1 \mathrm{DPPH}$ and $\mathrm{H}_{2} \mathrm{O}_{2}$ scavenging activities of selected plant extracts. Data represent the mean of three replicates

\section{Correlation between total phenolic content and $\mathrm{IC}_{50}$ values of antioxidants}

Quantitative analyses of antioxidants and phytochemicals were also used to investigate the correlation between phenolic contents and antioxidant activities (DPPH, $\mathrm{H}_{2} \mathrm{O}_{2}$ radical scavenging activities) in extracts of the selected plant species. The correlation coefficient $\left(R^{2}\right)$ between total phenolics, DPPH and $\mathrm{H}_{2} \mathrm{O}_{2}$ activities of the five studied plant extracts (Fig. 2) was found to be 0.93 .

\section{Antibacterial activity and determination of MIC and MBC}

The plant extracts exhibited considerable antibacterial activity against all the selected strains of microorganisms tested. Results obtained from the agar well diffusion method were used to determine the MIC and MBC (Table 5). The CP extract showed substantial activity against $P$. aeruginosa, $S$. aureus, $K$. pneumoneae and $A$. baumannii, with the lowest MIC values and MBC values, respectively. For activity against $A$. baumannii, $K$. pneumoneae, $P$. aeruginosa and $S$. aureus, CP gave

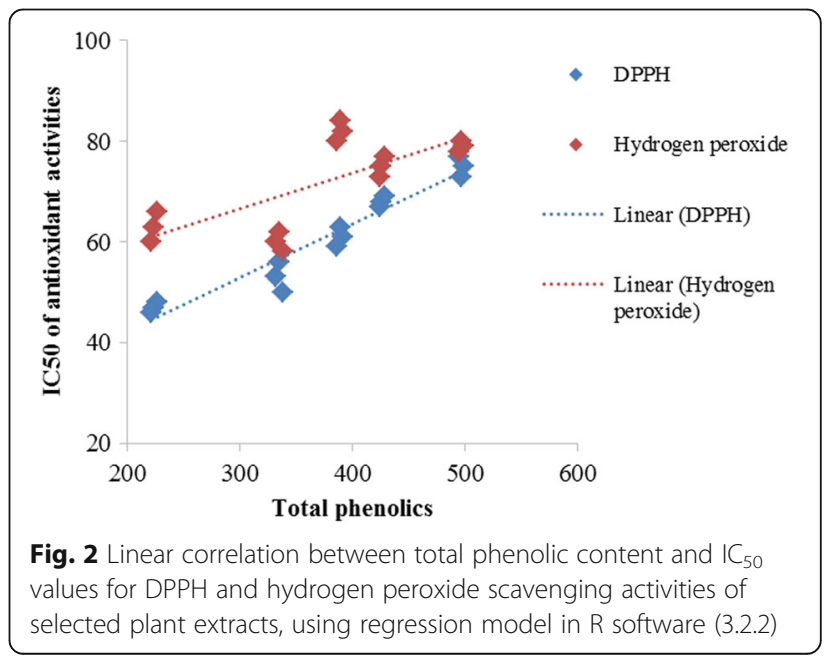


Table 5 Antibacterial activity determined as zone of inhibition ( $\mathrm{mm}$ ), minimum inhibitory concentration (MIC) and minimum bactericidal concentration (MBC) of selected plant extracts against selected bacterial strains

\begin{tabular}{|c|c|c|c|c|c|c|c|c|}
\hline & \multicolumn{8}{|c|}{ Zone of inhibition (mm) } \\
\hline Plant extracts & \multicolumn{2}{|l|}{ A. baumannii } & \multicolumn{2}{|l|}{ K. pneumoneae } & \multicolumn{2}{|c|}{ P. aeruginosa } & \multicolumn{2}{|l|}{ S. aureus } \\
\hline A. indica & \multicolumn{2}{|l|}{$14 \pm 1$} & \multicolumn{2}{|l|}{$13 \pm 1.4$} & \multicolumn{2}{|c|}{$16 \pm 1.2$} & \multicolumn{2}{|l|}{$15 \pm 1.3$} \\
\hline C. pedicellata & \multicolumn{2}{|l|}{$18 \pm 2$} & \multicolumn{2}{|l|}{$20 \pm 1.5$} & \multicolumn{2}{|c|}{$23 \pm 0.96$} & \multicolumn{2}{|l|}{$22 \pm 1.2$} \\
\hline M. indica & \multicolumn{2}{|l|}{$14 \pm 0.9$} & \multicolumn{2}{|l|}{$13 \pm 1.7$} & \multicolumn{2}{|c|}{$12 \pm 1.1$} & \multicolumn{2}{|l|}{$18 \pm 1.3$} \\
\hline T. terrestris (leaf) & \multicolumn{2}{|l|}{$15 \pm 1.2$} & \multicolumn{2}{|l|}{$16 \pm 1.2$} & \multicolumn{2}{|c|}{$19 \pm 1.3$} & \multicolumn{2}{|l|}{$17 \pm 1.1$} \\
\hline T. terrestris (fruit) & \multicolumn{2}{|l|}{$17 \pm 0.9$} & \multicolumn{2}{|l|}{$18 \pm 0.85$} & \multicolumn{2}{|c|}{$22 \pm 1.1$} & \multicolumn{2}{|l|}{$18 \pm 0.86$} \\
\hline \multirow[t]{3}{*}{ Streptomycin } & \multicolumn{2}{|l|}{$27 \pm 1.3$} & \multicolumn{2}{|l|}{$27 \pm 0.98$} & \multicolumn{2}{|c|}{$25 \pm 1.2$} & \multicolumn{2}{|l|}{$29 \pm 1.01$} \\
\hline & \multicolumn{2}{|l|}{ A. baumannii } & \multicolumn{2}{|c|}{ K. pneumoneae } & \multicolumn{2}{|l|}{ P. aeruginosa } & \multicolumn{2}{|l|}{ S. aureus } \\
\hline & MIC $(\mu \mathrm{g} / \mathrm{mL})$ & $\mathrm{MBC}(\mu \mathrm{g} / \mathrm{mL})$ & $\mathrm{MIC}(\mu \mathrm{g} / \mathrm{mL})$ & $\mathrm{MBC}(\mu \mathrm{g} / \mathrm{mL})$ & $\mathrm{MIC}(\mu \mathrm{g} / \mathrm{mL})$ & $\mathrm{MBC}(\mu \mathrm{g} / \mathrm{mL})$ & $\mathrm{MIC}(\mu \mathrm{g} / \mathrm{mL})$ & $\mathrm{MBC}(\mu \mathrm{g} / \mathrm{mL})$ \\
\hline A. indica & $150 \pm 4.5$ & $640 \pm 10$ & $90 \pm 1.5$ & $355 \pm 2.2$ & $55 \pm 1.21$ & $220 \pm 3.5$ & $200 \pm 4.3$ & $750 \pm 10$ \\
\hline C. pedicellata & $35 \pm 1.9$ & $150 \pm 6.3$ & $15 \pm 1.1$ & $85 \pm 1.1$ & $5 \pm 0.23$ & $40 \pm 1.2$ & $10 \pm 1$ & $55 \pm 1$ \\
\hline M. indica & $210 \pm 7.6$ & $820 \pm 11$ & $95 \pm 8.5$ & $390 \pm 2.3$ & $60 \pm 0.9$ & $200 \pm 3$ & $70 \pm 1.4$ & $250 \pm 2.1$ \\
\hline T. terrestris (leaf) & $50 \pm 2.1$ & $250 \pm 7.8$ & $30 \pm 1.1$ & $125 \pm 1.4$ & $10 \pm 0.57$ & $60 \pm 3.5$ & $15 \pm 1$ & $80 \pm 1.2$ \\
\hline T. terrestris (fruit) & $45 \pm 1.9$ & $200 \pm 6.5$ & $25 \pm 1$ & $100 \pm 1.1$ & $8 \pm 0.42$ & $50 \pm 2.9$ & $12 \pm 1$ & $70 \pm 1.1$ \\
\hline Streptomycin & $20 \pm 1.2$ & $90 \pm 1.8$ & $3 \pm 0.4$ & $10 \pm 0.5$ & $1 \pm 0.11$ & $3 \pm 0.3$ & $5 \pm 0.9$ & $15 \pm 1.4$ \\
\hline
\end{tabular}

the lowest MIC and MBC values, followed by TTF and TTL (Table 5).

\section{Antifungal activity}

Results of the assays for antifungal potential of the selected plant extracts are presented in Fig. 3. Methanolic extracts of $\mathrm{CP}$ were highly effective in inhibiting the mycelial growth of A. flavus ( $88 \%$ inhibition), followed by TTF and TTL (83\% and 79\%, respectively). The ranking order for antifungal potential of plant extracts against A. flavus was $\mathrm{CP}>\mathrm{TTF}>\mathrm{TTL}>\mathrm{MI}>\mathrm{AI}$.

$\mathrm{CP}$ extract exhibited the maximum reduction $(90 \%)$ in the mycelial growth of $A$. fumigatus, followed by
TTF and TTL (87\% and $85 \%$, respectively). The ranking order for the antifungal potential of plant extracts against $A$. fumigatus was $\mathrm{CP}>\mathrm{TTF}>\mathrm{TTL}>\mathrm{MI}>\mathrm{AI}$.

$\mathrm{CP}$ again was highly effective in inhibiting the mycelial growth (94\%) of $R$. oryzae, followed by TTF and TTL ( $93 \%$ and $90 \%$, respectively).

\section{Correlation between total phenolic content and antimicrobial activities}

Positive correlations were found between the phenolic contents of the selected methanolic plant extracts and inhibition of all of the tested bacteria and fungi (Fig. 4a, b). The correlation coefficients $\left(R^{2}\right)$ values for activity against

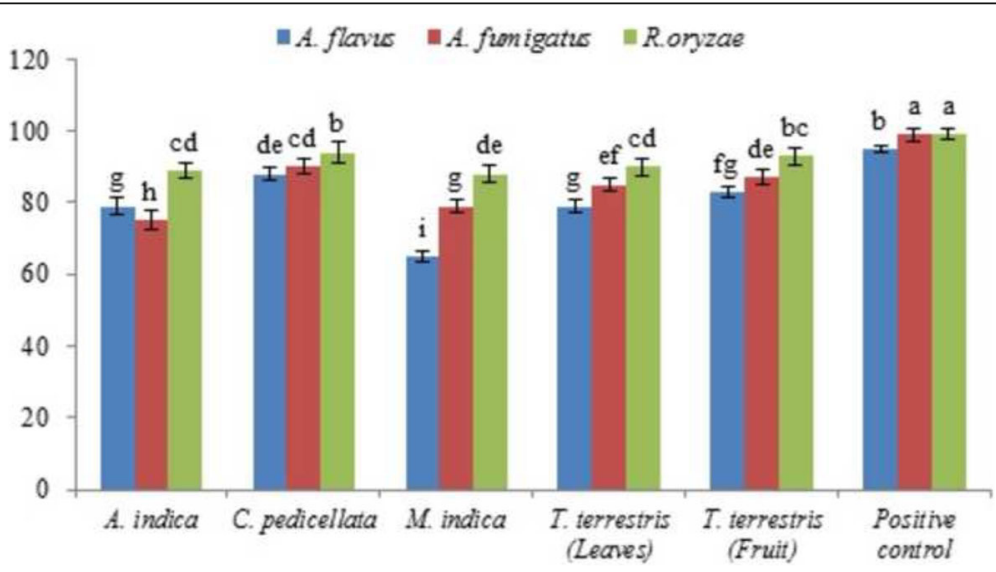

Fig. 3 Antifungal potential of methanolic extracts against A: Aspergillus flavus, B: Aspergillus fumigatus, C: Rhizopus oryzae, observed after $7 \mathrm{~d}$ of incubation. Data represent the mean of three replicates 


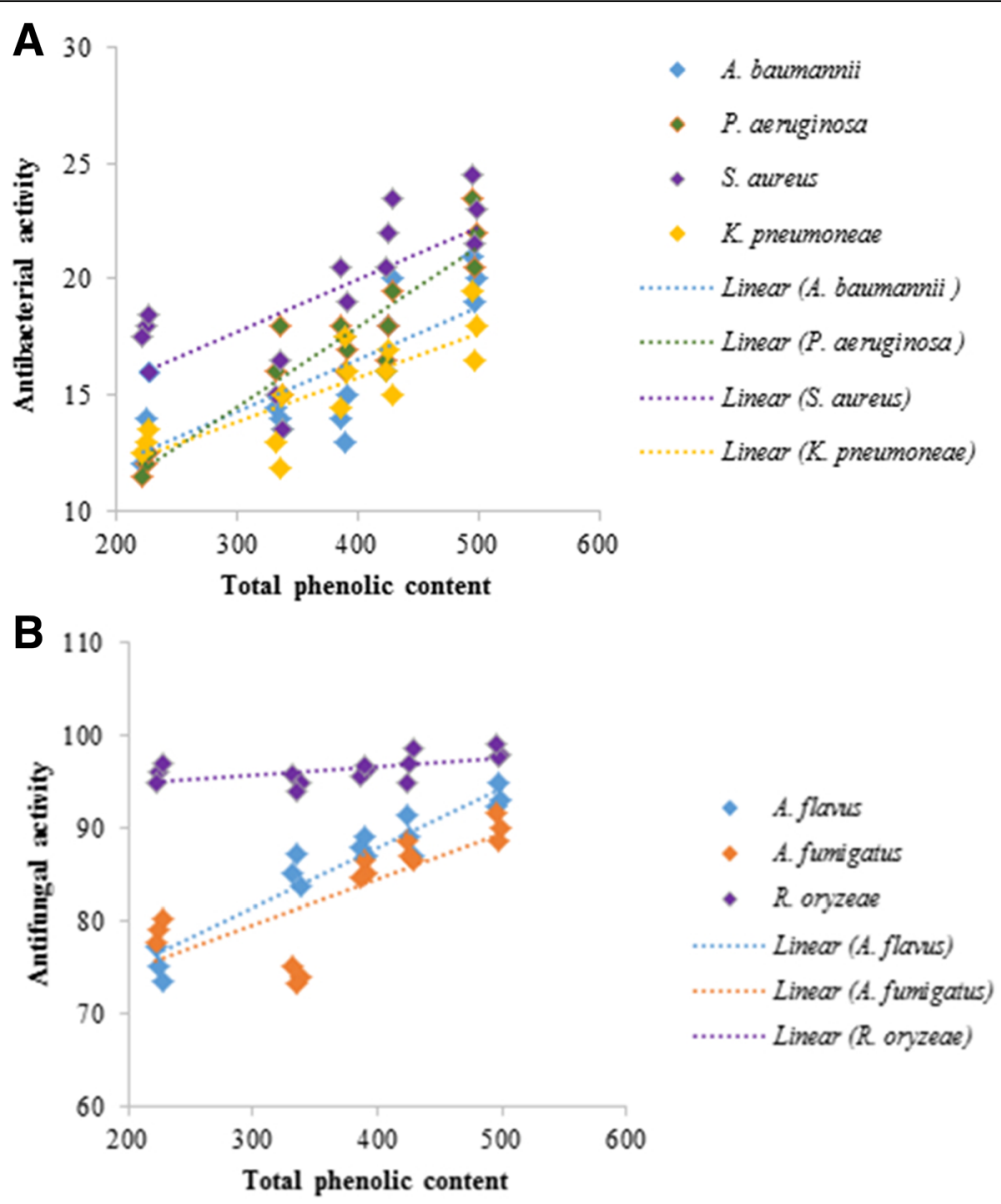

Fig. 4 Linear correlation between total phenolic content and (a): antibacterial activity and (b): antifungal activity of selected plant extracts

A. baumannii, K. pneumoneae, $P$. aeruginosa and S. aureus were found to be $0.55,0.66,0.87$ and 0.46 , respectively. The $\mathrm{R}^{2}$ values for total phenolic content and antifungal potential against A. flavus, A. fumigatus and $R$. oryzae were $0.92,0.70$ and 0.53 , respectively.

\section{Cytotoxic activity}

Methanolic plant extracts at three different concentrations $(10,100,1000 \mathrm{mg} / \mathrm{L})$ were tested for cytotoxicity (Table 6). All the plant extracts showed a cytotoxic effect against brine shrimp cells, with their effectiveness ranked $\mathrm{TTF}>\mathrm{TTL}>\mathrm{AI}>\mathrm{MI}>\mathrm{CP}$.

Table 6 Percentage mortality of brine shrimps at three different concentrations of plant extracts and respective $L_{50}$ values

\begin{tabular}{lllll}
\hline Plant extracts & $10 \mathrm{mg} / \mathrm{L}$ & $100 \mathrm{mg} / \mathrm{L}$ & $1000 \mathrm{mg} / \mathrm{L}$ & $\mathrm{LD}_{50} \mathrm{mg} / \mathrm{L}$ \\
\hline A. indica & 1.39 & 2.48 & 2.89 & 66 \\
C. pedicellata & 1.23 & 1.55 & 2.13 & 109 \\
M. indicus & 1.09 & 1.37 & 2.09 & 98 \\
T. terrestris (leaf) & 1.55 & 2.53 & 3.56 & 49 \\
T. terrestris (fruit) & 2.65 & 3.12 & 5.20 & 38 \\
\hline
\end{tabular}

\section{Anti-inflammatory and anti-proteinase activity}

Test plant extracts $(25-200 \mu \mathrm{g} / \mathrm{mL})$ inhibited albumin denaturation, hemolysis of HRBCs and proteinase activity (Table 7). Albumin denaturation inhibition at the highest concentration of $200 \mu \mathrm{g} / \mathrm{mL}$ was found in $\mathrm{CP}>\mathrm{TTF}>\mathrm{TTL}>\mathrm{AI}>\mathrm{MI}$. The $\mathrm{IC}_{50}$ of $\mathrm{CP}$ was $28 \mu \mathrm{g} / \mathrm{mL}$.

TTF exhibited the maximum inhibition (69\%) in the heat-induced hemolysis of HRBCs, followed by CP > TTL. The $\mathrm{IC}_{50}$ values for TTF, CP and TTL were 89,151 and $193 \mu \mathrm{g} / \mathrm{mL}$, respectively.

The maximum inhibition anti-proteinase activity (68\%) was exhibited by TTF at $200 \mu \mathrm{g} / \mathrm{mL}$, which was followed by $\mathrm{CP}$ and TTL. The $\mathrm{IC}_{50}$ values for TTF, CP and TTL were 95, 175 and $209 \mu \mathrm{g} / \mathrm{mL}$, respectively (Table 7).

\section{Correlation between total phenolic content, anti-inflammatory and anti-proteinase activity}

The IC50 values for albumin denaturation, membrane protection and proteinase inhibition were calculated (Fig. 5) and used to evaluate correlations with total 
Table 7 Albumin denaturation, membrane protection/ stabilization and proteinase inhibition potential of methanol extract of the selected plant species

\begin{tabular}{|c|c|c|c|c|}
\hline \multirow[t]{2}{*}{ Test sample } & \multirow[b]{2}{*}{$\begin{array}{l}\text { Conc. } \\
(\mu \mathrm{g} / \mathrm{mL})\end{array}$} & \multirow[b]{2}{*}{$\begin{array}{l}\text { Albumin } \\
\text { denaturation }\end{array}$} & \multicolumn{2}{|l|}{$\begin{array}{l}\text { Percent } \\
\text { inhibition }\end{array}$} \\
\hline & & & $\begin{array}{l}\text { Membrane } \\
\text { protection }\end{array}$ & $\begin{array}{l}\text { Proteinase } \\
\text { inhibition }\end{array}$ \\
\hline & 25 & $29.7 \pm 1.4$ & $26.1 \pm 0.9$ & $26 \pm 0.8$ \\
\hline \multirow[t]{3}{*}{ A. indica } & 50 & $37.1 \pm 1.5$ & $29.4 \pm 1.1$ & $28.8 \pm 1.1$ \\
\hline & 100 & $46.8 \pm 1.2$ & $35.7 \pm 1.0$ & $35.1 \pm 1.1$ \\
\hline & 200 & $61.4 \pm 1.0$ & $44.6 \pm 1.2$ & $43.9 \pm 1.5$ \\
\hline IC50 & & $129 \pm 4.6$ & $247 \pm 5.4$ & $256 \pm 5.4$ \\
\hline \multirow[t]{2}{*}{ Aspirin } & & $84.5 \pm 1.1$ & $93.7 \pm 1.0$ & $97.1 \pm 1.1$ \\
\hline & 25 & $43.1 \pm 0.8$ & $31.9 \pm 0.9$ & $30 \pm 1.0$ \\
\hline \multirow[t]{3}{*}{ C. pedicellata } & 50 & $59.5 \pm 0.9$ & $37 \pm 1.2$ & $34.8 \pm 1.3$ \\
\hline & 100 & $65.6 \pm 1.1$ & $47.6 \pm 1.3$ & $42.9 \pm 1.3$ \\
\hline & 200 & $73.3 \pm 1.3$ & $54.5 \pm 1.3$ & $52.1 \pm 1.5$ \\
\hline IC50 & & $28 \pm 1.1$ & $151 \pm 5.0$ & $175 \pm 5.2$ \\
\hline \multirow[t]{2}{*}{ Aspirin } & & $91.8 \pm 1.1$ & $110.9 \pm 1.3$ & $117.1 \pm 1.3$ \\
\hline & 25 & $17.7 \pm 1.5$ & $16.7 \pm 1.0$ & $16 \pm 1.1$ \\
\hline \multirow[t]{3}{*}{ M. indicus } & 50 & $25.3 \pm 1$ & $23.8 \pm 1.2$ & $21.9 \pm 1.2$ \\
\hline & 100 & $33.6 \pm 1.5$ & $24.9 \pm 1.4$ & $23.9 \pm 1.5$ \\
\hline & 200 & $48.7 \pm 1.5$ & $29.8 \pm 1.4$ & $27.6 \pm 1.5$ \\
\hline IC50 & & $203 \pm 5.6$ & $510 \pm 6.6$ & $577 \pm 7.2$ \\
\hline \multirow[t]{2}{*}{ Aspirin } & & $86.2 \pm 0.9$ & $95 \pm 1.2$ & $105.2 \pm 1.3$ \\
\hline & 25 & $39.1 \pm 1$ & $30.1 \pm 1.0$ & $28.5 \pm 1.1$ \\
\hline \multirow[t]{3}{*}{ T. terrestris (fruit) } & 50 & $57.6 \pm 1.1$ & $45 \pm 1.1$ & $43.6 \pm 1.2$ \\
\hline & 100 & $63.4 \pm 1.3$ & $59.7 \pm 1.3$ & $59 \pm 1.3$ \\
\hline & 200 & $71.8 \pm 1.5$ & $68.8 \pm 1.5$ & $67.9 \pm 1.5$ \\
\hline IC50 & & $43 \pm 1.3$ & $89 \pm 2.4$ & $95 \pm 2.7$ \\
\hline \multirow[t]{2}{*}{ Aspirin } & & $89.2 \pm 1.1$ & $95.4 \pm 1.2$ & $99.9 \pm 1.3$ \\
\hline & 25 & $30.7 \pm 1.0$ & $28.3 \pm 0.8$ & $27.8 \pm 0.9$ \\
\hline \multirow[t]{3}{*}{ T. terrestris (leaf) } & 50 & $38.3 \pm 1.1$ & $30.1 \pm 1.0$ & $29.4 \pm 1.0$ \\
\hline & 100 & $48.3 \pm 1.1$ & $37.3 \pm 1.3$ & $36.4 \pm 1.3$ \\
\hline & 200 & $63.6 \pm 1.3$ & $51.1 \pm 1.5$ & $49 \pm 1.6$ \\
\hline IC50 & & $120 \pm 3.9$ & $193 \pm 4.8$ & $209 \pm 5.6$ \\
\hline Aspirin & & $84.2 \pm 1.2$ & $96.8 \pm 1.3$ & $99.7 \pm 1.4$ \\
\hline
\end{tabular}

Values are means $\pm \operatorname{SD}(n=3)$

phenolic content. Positive correlations were found between anti-inflammatory, anti-proteinase activity and total phenolic content. High correlation coefficients $\left(R^{2}\right)$ values $(0.76,0.72$ and 0.996$)$ were found for albumin denaturation, membrane protection and proteinase inhibition, respectively. Therefore, total phenolic content might be used as an indicator in assessing the antiinflammatory and anti-proteinase activity of the plant extracts tested here.

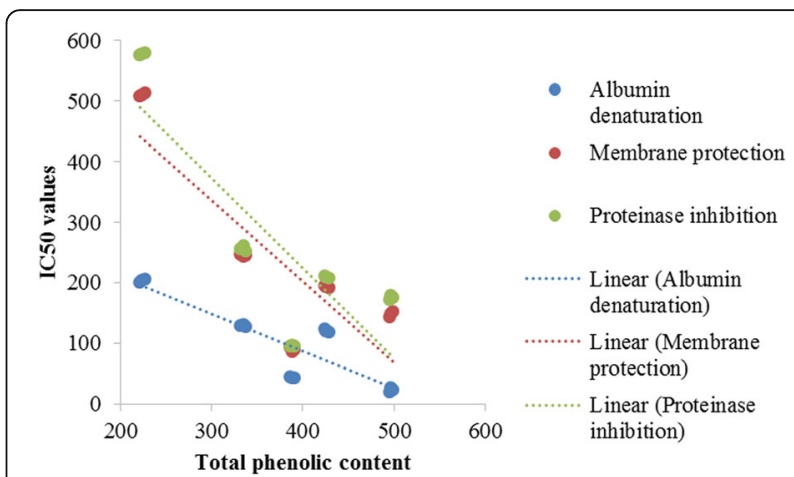

Fig. 5 Linear correlation of the total phenolic content versus the anti-inflammatory and anti-proteinase activity of selected plant extracts

\section{Discussion}

The medicinal importance of Aristolochia indica (AI), Cuscuta pedicellata (CP), Melilotus indicus (MI) and Tribulus terrestris (TT) is well appreciated and reported from an ethnobotanical perspective but the biological activities of these plants collected from Chowk Azam, particularly CP, have been insufficiently investigated.

The selected plant extracts contain phenolic, flavonoid, tannin, terpenoid, phlobatannin and anthraquinone compounds. TLC profiling of all selected plant extracts in a chloroform: methanol solvent system also strongly suggested the presence of several bioactive metabolites in these plants. Furthermore, the quantitative analysis of tested plants revealed that methanolic stem extracts of CP, TTF and TTL were rich in phenolics and flavonoids. According to Ali et al. [36], Cuscuta species contain alkaloids, some glycosides, tannins, flavonoids, steroids and phenolic compounds. We observed the maximum DPPH and $\mathrm{H}_{2} \mathrm{O}_{2}$ [37] radical scavenging activities in the plant extracts of CP, TTF and TTL.

Total phenolic content is considered an important indicator of the antioxidant potential of plant extracts [38]. The correlation coefficient between total phenolic content, DPPH and $\mathrm{H}_{2} \mathrm{O}_{2}$ scavenging activities found here suggests that the phenolic compounds of the selected plant extracts contributed $93 \%$ to their antioxidant activities. Similar results of positive correlations between phenolic content and antioxidant activities of several plant extracts have been documented in previous reports $[39,40]$.

In the present study, the lowest MIC and MBC was observed in $\mathrm{CP}$ and found to be highly effective against the selected bacterial pathogens, followed by TTF $>$ TTL extracts. Ali et al. [36] and Faiyyaz et al. [41] have also reported the antimicrobial potential of $C$. pedicellata. The present study also revealed the antifungal potential of plant extracts against A. flavus, A. fumigatus 
and $R$. oryzae. Supporting this data, various medicinal plants are reported to show significant antifungal activity against $A$. flavus [42-44]. The antimicrobial potential of plant extracts can be attributed to the presence of certain bioactive compounds such as phenolics, tannins, flavonoids and polyphenols [45]. Among all these biologically active compounds, Baydar et al. [46] confirmed phenolics as the most significant and active compounds against bacteria as well as fungi. Similarly, the results of antibacterial and antifungal activities obtained in the present study were correlated to their total phenolic contents. Positive correlations between total phenolics of selected plant extracts and their antibacterial as well as antifungal potential were obtained.

Extracts are considered non-toxic if the $\mathrm{LD}_{50}$ or $\mathrm{LC}_{50}$ is greater than $100 \mu \mathrm{g} / \mathrm{mL}$ in the brine shrimp lethality assay [47]. The mortality percentage and lethal dose $\left(L D_{50}\right)$ for $50 \%$ of the population of nauplii were determined using statistical analysis and a graph of the logarithm of extract dose against lethality percentage [48]. In the present study, the ranking order for cytotoxicity was TTF $>$ TTL > AI > MI > CP. These results are supported by the findings of Menon et al. [49] who reported the strong cytotoxicity of $T$. terrestris fruit extracts. The anti-carcinogenic potential and antitumor activity of $T$. terrestris fruit extracts [47] have also been reported. Our results are also in accord with those of Hossen et al. [50] who demonstrated the moderate cytotoxicity of Aristolochia indica methanol extract. According to the previously reported literature, the compounds that show brine shrimp toxicity also tend to have cytotoxic properties against cells of solid tumors found in humans [36].

Protein denaturation and stabilization of human red blood cell membranes were studied to further establish the mechanism of anti-inflammatory action of the traditionally used medicinal plants tested. Inflammation is usually associated with the denaturation of proteins. Results from the present study revealed that CP significantly inhibited protein/albumin denaturation. Methanolic stem extracts of $\mathrm{CP}$ had the highest anti-inflammatory potential (strong inhibition of protein denaturation), followed by the TTF and TTL extracts. The selected plant extracts were also effective in stabilizing $\mathrm{RBC}$ membranes or inhibiting the heatinduced hemolysis at different concentrations. Chowdhury et al. [51] also reported that methanolic leaf extracts of Gardenia coronaria promoted RBC membrane stability. Results from the present study provide evidence for membrane stabilization as an additional mechanism of their anti-inflammatory potential. The potential extracts $(\mathrm{CP}$, TTF, TTL and MI) might inhibit the release of the lysosomal content of neutrophils at inflammation sites but this would need to be investigated. The lysosomal constituents of neutrophils include protease and bactericidal enzymes, which upon extracellular release cause more damage and tissue inflammation [52].

Proteinases have been implicated in arthritic reactions. Neutrophils are reported to be a rich source of serine proteinases, which are localised in lysosomal granules. Leukocyte proteinases are involved in the development of tissue damage during inflammatory reactions and proteinase inhibitors provide substantial protection against this effect [53]. Methanol extracts of $O$. corniculata have been reported to have significant antiproteinase activity [54]. In the present study, high correlation coefficients values were found between total phenolic content and anti-inflammatory as well as anti-proteinase inhibition activity of the selected plant extracts.

\section{Conclusion}

Maximum antioxidant, antimicrobial and anti-inflammatory activities were observed in methanolic $\mathrm{CP}$ extracts, which showed strong positive correlations with phenolic content. Results from this study revealed that CP stem extracts and TTF and TTL extracts contain a substantial phenolic content, which was suggested to be the major contributor to their antioxidant, antibacterial, antifungal, anti-inflammatory and anti-proteinase activities. These extracts have potential to be used to prevent food spoilage and to treat inflammation as well as skin irritations. Future research work will be focused on the use of $\mathrm{CP}$ stem extracts to protect against peroxidative damage related to carcinogenesis. The effectiveness of extracts of the medicinal plants studied here, particularly of CP, should be further elucidated through additional toxicity and phytochemical analyses to discover effective pharmacological agents.

\section{Abbreviations \\ DPPH: 2,2-diphenyl-1-picrylhydrazyl; HRBCs: Human red blood cells; MBC: Minimal bactericidal concentration; MIC: Minimal inhibitory concentration; TLC: Thin layer chromatography}

\section{Acknowledgements}

The authors would like to thank the Higher Education Commission of Pakistan for providing funds to conduct this research.

\section{Funding}

Higher Education Commission of Pakistan provided the required financial support for the study. (Project Ref. No. IPFP/HRD/HEC/2014/1673)

\section{Availability of data and materials}

All the data is contained in the manuscript.

\section{Authors' contributions}

RN prepared and characterized the plant extracts and wrote the manuscript; HA carried out the antioxidant and antimicrobial activities; SN collected plant samples and information related to their traditional uses in the local area; ZUI assisted in the in vitro experiments; TY and AB designed the experiments; AW and SZ helped in the statistical analysis. THR made substantial contributions to drafting and revising the manuscript for intellectual content. All authors have read and approved the manuscript. 


\section{Competing interests}

The authors declare that they have no competing interests.

\section{Consent for publication}

The study subject participated on a volunteer basis and provided informed consent for the data publication.

\section{Ethics approval and consent to participate}

This study deals with an experimental protocol for human blood samples that was approved by the institutional ethical review board of COMSATS Institute of Information Technology, Islamabad Pakistan. The ethical review board approved the execution of a project entitled "Antimicrobial activity, toxicity and anti-inflammatory potential of methanolic extracts of four ethnomedicinal plant species from Punjab, Pakistan". Furthermore, the blood samples were collected after a signed informed consent from the participants of the study.

\section{Publisher's Note}

Springer Nature remains neutral with regard to jurisdictional claims in published maps and institutional affiliations.

\section{Author details}

'Department of Biosciences, COMSATS Institute of Information Technology, Islamabad, Pakistan. ${ }^{2}$ Department of Sociology and Anthropology, PMAS University of Arid Agriculture, Rawalpindi, Pakistan. ${ }^{3}$ Department of Plant Sciences, Quaid-i-Azam University, Isamabad, Pakistan. ${ }^{4}$ Department of Mathematics, COMSATS Institute of Information Technology, Islamabad, Pakistan. ${ }^{5}$ Plant Breeding Institute, Sydney Institute of Agriculture, University of Sydney, Sydney, NSW 2006, Australia.

\section{Received: 8 November 2016 Accepted: 31 May 2017} Published online: 08 June 2017

\section{References}

1. EL-Kamali HH, EL-Amir MY. Antibacterial activity and phytochemical screening of ethanolic extracts obtained from selected Sudanese medicinal plants. Curr Res J Biol Sci. 2010;2:143-6.

2. Tiwari P, Kumar B, Kaur M, Kaur G, Kaur H. Phytochemical screening and extraction: a review. Int Pharma Sci. 2011;1:98-106.

3. Chandran P, Vysakhi M, Manju S, Kannan M, Abdul KS, Sreekumaran NA. In vitro free radical scavenging activity of aqueous and methanolic leaf extracts of Aegle tamilnadensis Abdul Kader (Rutaceae). Int J Pharm Pharm Sci. 2013;5:819-23.

4. Chamundeeswari D, Vasantha J, Gopalakrishna S, Sukumar E. Free radical scavenging activity of the alcoholic extract of Trewia polycarpa roots in arthritic rats. E J Ethnopharmacol. 2003;88:51-6.

5. Qin HY, Wu JCY, Tong XD, Sung JJY, Xu HX, Bian ZX. Systematic review of animal models of post-infectious/post-inflammatory irritable bowel syndrome. J Gastroenterol. 2011;46:164-74.

6. Ahmed N, Mahmood A, Mahmood A, Tahir SS, Bano A, Malik RN, et al. Relative importance of indigenous medicinal plants from Layyah district, Punjab Province. Pakistan J Ethnopharma. 2014;155:509-23.

7. Kumar D, Kumar A, Prakash O. Potential antifertility agents from plants: a comprehensive review. J Ethnopharmacol. 2012;140:1-32.

8. Nickrent DL. Phylogenetic origins of parasitic plants. Parasitic plants of the Iberian Peninsula and Balearic Islands. 2002;3:29-56.

9. Hassanein EE, Ibrahim HM, Kholosy AS, Al-Marsafy HT, Abo Elenin RA. Manual of weed identification and control in wheat. Agricultural Research Center, Giza, Egypt. 2000;144

10. Prusty KB, Mamatha CH, Harish B, Subudhi SK. Phytochemical and pharmacological evaluation of different extracts of leaves of Tribulus terrestris Linn. J Pharma Phytotherap. 2013;1:15-8.

11. Quignard ELJ, Pohlit AM, Nunomura SM, Pinto ACS, dos Santos EVM, de Morais SKR, et al. Screening of plants found in Amazonas state for lethality towards brine shrimp. Acta Amazon. 2003;33:93-104.

12. Harborne JB. Phytochemical methods. A guide to modern techniques of plant analysis. London, New York: Chapman and Hall Ltd. 1973;49-188.

13. Trease GE, Evans WC. Pharmacognosy. 11th ed. London: Brailliar Tiridel CanMacmillan Publishers. 1989;60-75.

14. Sofowora AE. Recent trends in research into African medicinal plants. J Ethnopharmacol. 1993;389:209-14.
15. Chlopicka J, Pasko P, Gorinstein S, Jedryas A, Zagrodzki P. Total phenolic and total flavonoid content, antioxidant activity and sensory evaluation of pseudocereal breads. LWT-Food Sci Technol. 2012;46:548-55.

16. Chang CC, Yang MH, Wen HM, Chern JC. Estimation of total flavonoid content in propolis by two complementary colorimetric methods. J Food Drug Anal. 2002;10:178-82.

17. Stanković MS. Total phenolic content, flavonoid concentration and antioxidant activity of Marrubium peregrinum L. extracts. Kragujevac J Sci. 2011;33:63-72.

18. Pattanayak SP, Mazumder PM. Therapeutic potential of Dendrophthoe falcata (If) Ettingsh on 7, 12-dimethylbenz (a) anthracene-induced mammary tumorigenesis in female rats: effect on antioxidant system, lipid peroxidation, and hepatic marker enzymes. Comp Clinical Pathol. 2011;20:381-92.

19. Kalita P, Tapan BK, Pal TK, Kalita R. Estimation of total flavonoids content (TFC) and antioxidant activities of methanolic whole plant extract of Biophytum sensitivum Linn. J Drug Delivery Therap. 2013;3:33-7.

20. Brand-Williams W, Cuvelier ME, Berset CL. Use of a free radical method to evaluate antioxidant activity. Food Sci Technol. 1995;28:25-30.

21. Koksal E, Bursal E, Dikici E, Tozoglu F, Gulcin I. Antioxidant activity of Melissa officinalis leaves. J Med Plants Res. 2011;5:217-22.

22. Blois MS. Antioxidant determinations by the use of a stable free radical. Nature. 1958;181:199-1200.

23. Yamasaki K, Hashimoto A, Kokusenya Y, Miyamoto T, Sato T. Electrochemical method for estimating the antioxidative effects of methanol extracts of crude drugs. Chem Pharma Bulletin. 1994;42:1663-5.

24. Ruch RJ, Cheng SJ, Klaunig JE. Prevention of cytotoxicity and inhibition of intercellular communication by antioxidant catechins isolated from Chinese green tea. Carcinogenesis. 1989;10:1003-8.

25. Jayaprakasha GK, Rao L, Sakariah KK. Antioxidant activities of flavonoid in different in vitro model systems. Bioorg Med Chem. 2004;12:5141-6.

26. Valgas C, De Souza SM, Smânia EFA, Smânia A. Screening methods to determine antibacterial activity of natural products. Braz J Microbiol. 2007:38:369-80.

27. Clinical and Laboratory Standards Institute (CLSi): Methods for Dilution Antimicrobial Susceptibility Tests, fourth ed. Wayne, PA, USA; 2008. Approved Standard, M7-A4.

28. Washington JAU, Sutter VL. Dilution susceptibility test: agar and macrobroth dilution procedures. In: Lenette EH, editor. Manual of clinical microbiology. 3rd ed. Washington, D.C.: American Society for Microbiology; 1980. p. 453-8.

29. Meyer AA, Hartmann H, Sumpel F, Cruetzfeld W. Mechnism of insulin resistance in CCl4-induced cirrhosis of rats. Gastroenterology. 1992;102:223-9.

30. Patil $S B$, Magdum CS. Determination of $L_{50}$ values of extract of Euphorbia hirta Linn and Euphorbia nerifolia Linn using brine shrimp lethality assay. Asian J Res Pharm. 2011;1:42-3.

31. Mizushima Y, Kobayashi M. Interaction of anti-inflammatory drugs with serum preoteins, especially with some biologically active proteins. J Pharm Pharmacol. 1968;20:169-73.

32. Sadique J, Al-Rqobahs WA, Bughaith, AR EIG. The bioactivity of certain medicinal plants on the stabilization of RBC membrane system. Fitoterapia. 1989;60:525-32.

33. Shinde UA, Phadke AS, Nari AM, Mungantiwar AA, Dikshit VJ, Saraf MN. Membrane stabilization activity-a possible mechanism of action for the antiinflammatory activity of Cedrus deodara wood oil. Fitoterapia. 1999;70:251-7.

34. Oyedepo OO, Femurewa AJ. Anti-protease and membrane stabilizing activities of extracts of Fagra zanthoxiloides, Olax subscorpioides and Tetrapleura tetraptera. Int J Pharm. 1995;33:65-9.

35. Gomez KA, Gomez AA. Statistical Procedure for Agricultural Research. New York: John Wiley and Sons; 1984.

36. Ali A, Haider MS, Hanif S, Akhtar N. Assessment of the antibacterial activity of Cuscuta pedicellata Ledeb. Afr J Biotechnol. 2014;13:430-3.

37. Pazdzioch-Czochra M, Widenska A. Spectrofluorimetric determination of hydrogen peroxide scavenging activity. Anal Chim Acta. 2002;452:177-84.

38. Wang H, Gan D, Zhang X, Pan Y. LWT Food Sci Technol. 2010;43:319-25.

39. Zhang Y, Li X, Wang Z. Food Chem Toxicol. 2010;48:2656-62.

40. El-Chaghaby GA, Ahmad AF. Ramis ES. Evaluation of the antioxidant and antibacterial properties of various solvents extracts of Annona squamosa L. leaves. Arab J Chem. 2014;7:227-33.

41. Faiyyaz IB, Rajesh OJ, Trushal CV, Kapli G. In vitro antimicrobial activity of Cuscuta reflexa ROXB. Int Res J Pharm. 2011;2:214-6. 
42. Saraf S, Jeswani G, Kaur CD, Saraf S. Development of novel herbal cosmetic cream with Curcuma longa extract loaded transfersomes for antiwrinkle effect. Afr J Pharm Pharmacol. 2011;5(8):1054-62.

43. Mahesh B, Satish S. Antimicrobial activity of some important medicinal plant against plant and human pathogens. World J Agri Sci. 2008;4:839-43.

44. Ouattara L, Koudou J, Zongo C, Barro N, Savadogo A, Bassole IHN, et al. J Appl Sci. 2011;11:157-62.

45. Baydar NG, Ozkan H, Sagdic O. Total phenolic contents and antibacterial activities of grape (Vitis vinifera L.) extracts. Food Control. 2004;15:335-9.

46. Gupta MP, Monge A, Karitas G. Lopez de, Cerain A, Solis PN, Leon E, de Trujilo M, Surez O, Wilson F, Montenegro G, Noriega Y, Santana Al, Correa M. Sanchez C Intr J Pharmacol. 1996;34:123-7.

47. McLughilin JL, Rogers LL. Drug Info J. 1991;32:513-24.

48. Menon DK, Dharmapal S, Achuthan CR, Babu TD. Cytotoxic and antitumor effects of Tribulus terrestris $L$ fruit methanolic extract. J Pharmacog Phytochem. 2014;3:1-4.

49. Hossen SMM, Hossain MS, Islam J, Pinto MN, Jannat NE, Ahmed F. Comparative preliminary phytochemical and biological investigations on Andrographis paniculata (Nees) and Aristolochia indica (Linn). Der Pharma Chemica. 2014;6:332-8.

50. Kishore DV, Rahman R. Spasmolytic activity of Casuarina equisetifolia bark extract. Int J Pharm Sci Res. 2012;3:1452-6.

51. Chowdhury A, Azam S, Jainul MA, Faruq KO, Islam A. Antibacterial activities and In Vitro anti-inflammatory (membrane stability) properties of Methanolic extracts of Gardenia coronaria leaves. Int J Microbiol. 2014:1-5.

52. Chou CT. The anti-inflammatory effect of Tripterygium wilfordii hook F on adjuvantinduced paw edema in rats and inflammatory mediators release. Phytother Res. 1997;11:152-4.

53. Das SN, Chatterjee S. Long term toxicity study of ART-400. Indian Indg Med. 1995;16:117-23.

54. Sakat SS, Juvekar AR, Gambhire M. In vitro antioxidant and anti-inflammatory activity of methanol extract of Oxalis corniculata linn. Int J Pharm Pharm Sci. 2010:2:146-55

\section{Submit your next manuscript to BioMed Central and we will help you at every step:}

- We accept pre-submission inquiries

- Our selector tool helps you to find the most relevant journal

- We provide round the clock customer support

- Convenient online submission

- Thorough peer review

- Inclusion in PubMed and all major indexing services

- Maximum visibility for your research

Submit your manuscript at www.biomedcentral.com/submit

) Biomed Central 